\title{
Pengembangan sistem kearsipan elektronik surat masuk dan surat keluar berbasis website pada unit tata usaha SMK pgri 2 Malang
}

\author{
Amanda Safitri, Imam Bukhori* \\ Universitas Negeri Malang, Jl. Semarang No. 5 Malang, Jawa Timur, Indonesia \\ *Penulis korespondensi, Surel: imbuchori@um.ac.id
}

Paper received: 3-5-2021; revised: 24-5-2021; accepted: 28-5-2021

\begin{abstract}
Abstrak
Teknologi informasi dan komunikasi yang dijalankan dengan baik dapat meningkatkan produktivitas serta efisiensi dalam melaksanakan pekerjaan kegiatan organisasi khususnya dalam bidang arsip. Menurut penuturan dari karyawan unit tata usaha di SMK PGRI 2 Malang masih menggunakan cara manual dan konvensional serta belum tertata dengan baik yang menimbulkan permasalahan seperti arsip yang hilang dan susahya untuk menemukan kembali arsip. Tujuan penelitian dan pengembangan adalah Menghasilkan aplikasi sistem penyimpanan arsip berbasis website melalui uji coba kelayakan untuk mempermudah penyimpanan arsip di SMK PGRI 2 Malang. Model penelitian ini menggunakan model pengembangan yang dikemukakan oleh Borg \& Gall yang telah dimodifikasi menjadi delapan langkah, teknik pengumpulan data berupa angket dengan skala likert. Data yang diperoleh berupa data kuantitatif dan data kualitatif. Teknik analisis data kuantitatif menggunakan rumus persentase untuk kemudian dikategorikan dalam jenjang kevalidan.Hasil penelitian ini berupa sistem kearsipan elektronik menggunakan basis website untuk mendukung kegiatan pengolahan arsip agar berjalan dengan efektif dan efisien. Sistem bernama siperi dapat diakses dengan menggunakan smartphone maupun PC yang diakses secara online dengan web address siperi.tech. siperi dilengkapi beberapa menu yang seperti penyimpanan arsip,peminjaman arsip, laporan arsip.
\end{abstract}

Kata kunci: sistem kearsipan elektronik; surat masuk; surat keluar; website

\section{Pendahuluan}

Teknologi informasi dan komunikasi yang dijalankan dengan baik dapat meningkatkan produktivitas serta efisiensi dalam melaksanakan pekerjaan. Pratiwi dalam (Nyfantoro, Salim and Mirmani, 2020) memaparkan bahwa perkembangan ilmu pengetahuan dan teknologi telah banyak mempengaruhi kegiatan organisasi khususnya dalam bidang arsip saat ini, seperti perubahan cara bekerja dan berkomunikasi, perubahan pemahaman mengenai efisiensi, perubahan dalam penciptaan, pengelolaan dan penggunaan informasi/arsip, dan perubahan bagi arsiparis dalam mengelola arsip.

Arsip merupakan bagian vital dari suatu instansi, baik instansi pemerintah, swasta maupun pendidikan, kegiatan administrasi di berbagai instansi terutama di dunia pendidikan digunakan untuk pelayanan baik untuk peserta didik, wali peserta didik, staf dan guru serta civitas akademik lainya. Sehingga pihak sekolah selain melakukan pembaharuan dalam sistem pembelajaran hendaknya juga melakukan pembaharuan dalam sistem administrasi agar kegiatan administrasi yang dilakukan di sekolah dapat berjalan dengan efektif dan sesuai dengan kemajuan yang ada di masyarakat. Salah satu bentuk pembaharuan dalam sistem arsip adalah dengan menggunakan sistem kearsipan elektronik atau e-arsip.

This work is licensed under a Creative Commons Attribution-ShareAlike 4.0 International License. 
Arsip elektronik adalah data (arsip) yang dapat disimpan dan dapat dipindahkan dalam bentuk terpisah yang dapat dibuka, dibuat atau dihapus dengan alat komputer yang dapat digunakan untuk mengolah arsip, sehingga arsip dapat pergunakan atau dimanfaatkan kembali. (Muhidin, Winata and Santoso, 2018). Penggunaan Arsip secara digital atau elektronik memberikan banyak manfaat baik untuk admin maupun pengguna, dengan menggunakan arsip elektronik pekerjaan pengarsipan dapat berlangsung secara efektif dan efisien.

Penanganan arsip secara elektronik sama dengan penanganan arsip secara manual baik surat masuk maupun surat keluar. Surat masuk merupakan surat yang berasal atau surat yang diterima dari instansi luar sedangkan surat keluar adalah surat yang dibuat oleh suatu instansi untuk dikirimkan kepada instansi maupun orang lain. Pada era ini surat ditulis dengan menggunakan Microsoft word dan dapat dikirim melalui e-mail Dengan memanfaat internet dan juga gadget yang dimiliki oleh sebagian besar manusia sehingga untuk pembuat surat baru serta melakukan pengarsipan dimanapun berada, dalam menerapkan hal tersebut salah satu media yang dapat dipilih adalah dengan menggunakan website.

Website adalah halaman maupun data yang saling terhubung memuat berbagai informasi yang terkait berupa teks, audio, gambar \& video. (Andi, 2011). Manusia selalu membutuhkan keterbaruan dan inovasi untuk menunjang kebutuhan kehidupan sehari-hari agar dapat berjalan dengan efektif dan efisien. Salah satu bentuk keterbaruan dan inovasi dalam pengelolaan arsip khususnya dalam penyimpanan arsip adalan Penggunaan website. Website dapat dijadikan sebagai sarana informasi yaitu dapat mempercepat penyimpanan dan penemuan kembali arsip sehingga $r$ arsiparis dapat berjalan secara praktis, efektif dan efisien, serta dapat menghemat biaya penggunaan kertas dan tempat dalam melakukan pengarsipan karena website dapat digunakan sebagai wadah dalam penyimpanan arsip secara elektronik. Dari pemaparan tersebut perkembangan teknologi terhadap pelaksanaan kegiatan kearsipan penting dilakukan sehingga menuntut setiap instansi dapat memiliki dan menggunakan sistem berbasis teknologi informasi.

Hasil kegiatan pra penelitian dikemukakan bahwa kegiatan pengelolaan surat di unit tata usaha SMK PGRI 2 Malang masih dilakukan dengan cara manual. Dalam pengelolaan surat pegawai tata usaha masih melakukan pencatatan surat secara manual dengan menggunakan buku agenda konvensional dengan cara menulis tangan serta penyimpanan arsip yang dilakukan dengan menjadikan berbagai subjek surat dalam satu map. Permasalahan tersebut menyebabkan sulitnya penemuan kembali arsip dan sering terjadi kehilangan arsip.

Pada SMK PGRI 2 Malang Terdapat beberapa komputer yang telah tersedia di dalam kantor yang dilengkapi dengan mesin print serta jaringan wifi selain itu para pegawai tata usaha juga tergolong terampil dalam mengoperasikan komputer. Meskipun teknologi sudah tersedia namun, pada kenyataannya praktek administrasi surat menyurat masih dilakukan secara konvensional. Sehingga perlu dilakukan sebuah bentuk pembaharuan dalam penyimpanan arsip terutama dalam bentuk penyimpanan arsip secara elektronik. 


\section{Metode}

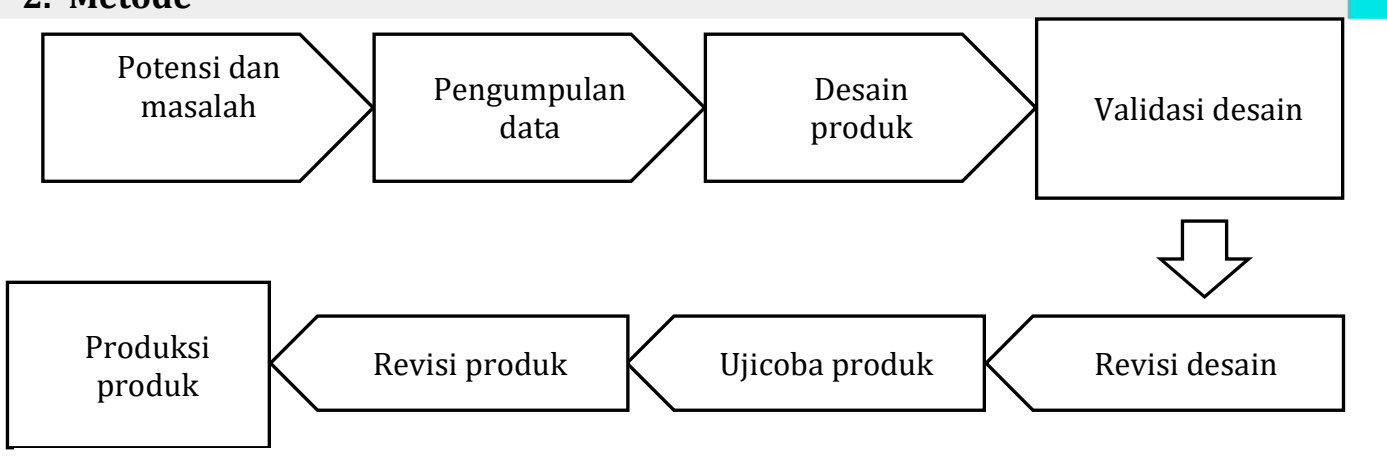

Gambar 1. Metode Penelitian Pengembangan

\section{(Sumber Sugiyono (2011: 298)}

Pada penelitian ini menggunakan metode pengembangan yang dikemukakan oleh Borg \& Gall, Metode penelitian pengembangan merupakan jenis penelitian dengan tujuan untuk menghasilkan produk baru atau mengembangkan dan memperbaharui produk yang ada sebelumnya dengan melakukan pengujian kelayakan serta keefektifan penggunaan produk (Sugiyono, 2011). Metode penelitian pengembangan yang dikemukakan oleh Borg \& Gall memiliki 10 tahap penelitian yang kemudian karena kebutuhan dari produk tidak perlu memerlukan produksi secara masal sehingga dilakukan modifikasi terhadap tahapan penelitian tersebut sehingga menjadi 8 tahap penelitian yaitu tahap potensi dan masalah, pengumpulan data, desain produk, validasi desain, revisi desain, uji coba produk, revisi produk dan produksi produk.

Pada tahapan pertama yaitu potensi dan masalah merupakan tahapan analisis potensi dan juga permasalahan yang terjadi di lapangan, pada tahap ke 2 yaitu pengumpulan data pengumpulan data merupakan tahapan pengumpulan informasi sebagai bahan untuk perancangan produk, pada tahapan ini pengumpulan data diperoleh melalui wawancara terhadap objek. Tahapan ke 3 yaitu desain produk merupakan proses perancangan produk sesuai dengan informasi kebutuhan serta permasalahan yang sering terjadi, pada tahap ke 4 merupakan tahapan validasi desain, validasi desain merupakan tahapan uji coba yang dilakukan kepada validator atau ahli dalam penelitian ini terdapat 2 validator yaitu validator ahli media yang bertujuan untuk memberikan penilaian serta masukan mengenai kualitas dan kelayakan pada sistem, serta validator ahli materi yang bertujuan untuk memberikan penilaian berupa kelayakan serta kesesuaian materi terhadap kebutuhan yang ada di lapangan. Tahap ke 5 merupakan revisi produk, revisi produk dilakukan berdasarkan masukan yang diberikan oleh validator, tahap ke 6 merupakan tahapan uji coba produk, produk diujicobakan terhadap pengguna pengguna merupakan 4 karyawan unit tata usaha SMK PGRI 2 Malang yang bertugas menangani bagian persuratan. dengan tujuan untuk memberikan pemahaman terhadap pengguna mengenai penggunaan produk serta untuk mengetahui respon pengguna terhadap penggunaan produk yang digunakan agar pekerjaan mereka dapat berjalan secara lebih efektif dan efisien,

Tahap ke 7 merupakan revisi produk, revisi produk dilakukan berdasarkan masukan yang diberikan oleh pengguna, tahap ke 8 merupakan produksi produk merupakan bentuk produk yang telah diuji kelayakan dan keefektifanya serta telah disesuaikan berdasarkan masukan yang diberikan dan telah disesuaikan berdasarkan kebutuhan di lapangan. 
Data yang diperoleh pada penelitian ini berupa data kuantitatif dan data kualitatif, dimana data kualitatif diperoleh melalui wawancara serta masukan yang diberikan oleh ahli media, ahli materi serta pengguna, sedangkan data kuantitatif diperoleh berdasarkan perhitungan skor pada pengisian angket yang diberikan kepada ahli materi, ahli media dan juga pengguna. Data kuantitatif yang diperoleh kemudian dihitung dengan menggunakan metode persentase deskriptif yang kemudian akan diperoleh angka persentase yang digunakan untuk menarik kesimpulan tingkat kelayakan dan keeektifan penggunaan produk.

\section{Hasil dan Pembahasan}

Produk yang dihasilkan pada penelitian pengembangan ini berupa sistem kearsipan elektronik berbasis website yang dapat digunakan untuk minangkat kerja dan efektifitas pegawai, sistem kearsipan elektronik ini hanya dapat diakses secara online dan dapat digunakan melalui PC maupun smartphone sehingga penggunaan aplikasi ini dapat dijalankan secara fleksibel. Siperi dilengkapi dengan menu-menu pendukung penyimpanan arsip secara efisien seperti penyimpanan surat masuk dan surat keluar, buku register, peminjaman arsip, lembar disposisi, serta cetak laporan arsip, selain itu siperi juga dilengkapi dengan sistem keamanan berupa username dan sandi sehingga pengguna tidak dapat mengakses sebelum didaftarkan oleh admin.
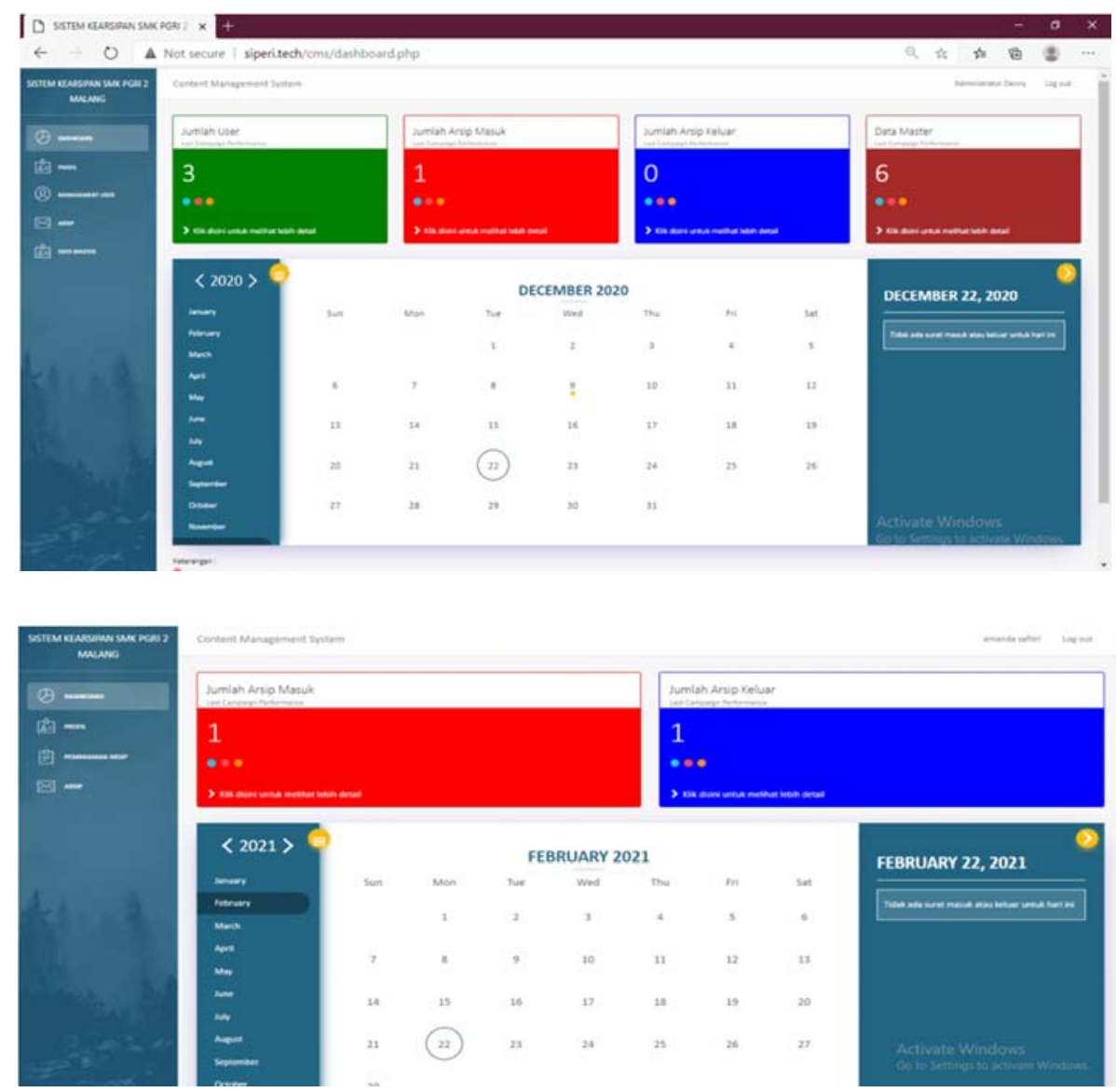

Gambar 2. Tampilan website siperi.tech 
Hasil validasi aplikasi siperi (sistem kearsipan SMK PGRI 2 Malang) yang dilakukan kepada ahli materi, ahli media serta uji coba produk menunjukkan persentase sebagai berikut:

Tabel 1. Hasil persentase data

\begin{tabular}{llll}
\hline No & Validasi & Persentase & Kriteria Validitas \\
\hline 1. & Ahli Media & $82 \%$ & Sangat Layak \\
2. & Ahli Materi & $93 \%$ & Sangat Layak \\
3 & Pengguna & $84 \%$ & Sangat setuju \\
\hline
\end{tabular}

Berdasarkan Tabel 1, diketahui rata-rata persentase validasi ahli media sebesar 82\%, ahli materi sebesar 93\% serta pengguna sebesar $84 \%$ sehingga dapat disimpulkan bahwa sistem kearsipan berbasis website yang dikembangkan peneliti 'Sangat Valid' dan layak digunakan dalam kegiatan administrasi pada Unit Tata Usaha SMK PGRI 2 Malang.

Peneliti mengemas berbagai kebutuhan administrasi persuratan yang dibutuhkan pada Unit Tata Usaha SMK PGRI 2 Malang dalam bentuk menu-menu yang mudah untuk dipahami dan menggunakan hosting di internet sehingga sistem dapat diakses melalui gadget dan smartphone serta dapat digunakan dimanapun berada dan dapat diakses dimanapun berada dengan memanfaatkan internet sehingga pekerjaan pegawai dalam mengelola arsip dapat berjalan dengan efektif dan efisien. Hal tersebut sejalan dengan pernyataan Tarigan,dkk (2018) yang menyatakan bahwa Teknologi informasi dalam pengelolaan arsip dapat memberikan manfaat berupa meningkatkan efektivitas pegawai baik arsiparis maupun non arsiparis. Adanya aplikasi e-arsip memberikan manfaat kepada pegawai berupa pengelolaan arsip secara tepat waktu. Serta dapat meringankan pekerjaan pegawai. aplikasi e-arsip membuat Pengelolaan arsip lebih cepat dan tepat jika dibandingkan dengan sistem manual. sehingga pengembangan dengan mengubah sistem konvensional menjadi penyimpanan arsip secara elektronik bermanfaat untuk meningkatkan efektivitas pekerjaan pegawai

Pemanfaatan teknologi digital dan diakses secara online dengan tujuan agar dalam kegiatan pengelolaan arsip dalam lebih efektif dan efisien, sistem ini dapat digunakan beberapa pengguna dalam waktu yang bersamaan dengan memakai perangkat yang berbeda dikarenakan sistem yang bersifat online sehingga dapat berjalan secara fleksibel yang dapat membuat kinerja pegawai akan lebih efektif dikarenakan dapat meminimalisir waktu yang terbuang (Geovanne Farell, Hadi Kurnia Saputra, 2018)

Hasil dari uji coba produk melalui pengisian angket memperoleh persentase sebesar 84\% menunjukkan bahwa produk SIPERI efektif digunakan dalam pengelolaan arsip khususnya penyimpanan dan penemuan kembali surat masuk dan surat keluar yang ada pada Unit Tata Usaha SMK PGRI 2 Malang. Hal tersebut sejalan dengan pernyataan bahwa sistem dapat memudahkan pegawai dalam hal persuratan, sehingga pekerjaan yang sebelumnya dilakukan secara manual bisa lebih efisien dan terkomputerisasi dengan baik (Vironica, 2013)

\section{Simpulan}

Berdasarkan kajian produk pengembangan yang dihasilkan peneliti, dapat dibuat kesimpulan sebagai berikut. Penelitian dan pengembangan ini menghasilkan Sistem Kearsipan berbasis website yang digunakan untuk kegiatan administrasi arsip pada SMK PGRI 2 Malang. Sistem kearsipan berbasi website yang dihasilkan dinyatakan "sangat valid" dan tepat digunakan untuk kegiatan administrasi arsip yang ada pada Unit Tata Usaha SMK PGRI 2 
Malang berdasarkan hasil validasi ahli materi, validasi ahli media, dan uji coba Penggunaan. SIstem Kearsipan berbasis website yang dikembangkan lebih efektif daripada sistem kearsipan secara konvensional yang digunakan pada Unit Tata Usaha SMK PGRI 2 Malang, dimana hasil tersebut diperoleh melalui pernyataan pengguna terhadap angket yang diberikan.

\section{Ucapan Terima Kasih}

Penulis mengucapkan terimakasih kepada Universitas Negeri Malang dan SMK PGRI 2 Malang yang telah memfasilitasi dan memberi izin kepada peneliti untuk melakukan kegiatan penelitian dan pengembangan ini.

\section{Daftar Rujukan}

Andi (2011) Membangun Website tanpa Modal. yogyakarta: andi.

Geovanne Farell, Hadi Kurnia Saputra, I. N. (2018) 'Rancang Bangun Sistem Informasi Pengarsipan Surat Menyurat (Studi Kasus Fakultas Teknik Unp)', Jurnal Teknologi Informasi dan Pendidikan, 11(2), 55-62.

Muhidin, S. A., Winata, H. and Santoso, B. (2018) 'Pengelolaan Arsip Digital', Pendidikan Bisnis \& Manajemen, 2(3), pp. 425-426. Available at: http://journal2.um.ac.id/index.php/jpbm/article/view/1708.

Nyfantoro, F., Salim, T. A. and Mirmani, A. (2020) 'Perkembangan Pengelolaan Arsip Elektronik di Indonesia: Tinjauan Pustaka Sistematis', Diplomatika: Jurnal Kearsipan Terapan, 3(1), p. 1. doi: 10.22146/diplomatika.48495.

Sugiyono (2011) Metode Penelitian Pendidikan Pendekatan Kuantitatif, Kualitatif Dan R\&D. Bandung: Alfabeta.

Tarigan, A. D. L. and Jumino, J. (2018) ‘Pemanfaatan Aplikasi E-Surat Dalam Mendukung Pengelolaan Arsip Dinamis Aktif Di Dinas Kearsipan Dan Perpustakaan Provinsi Jawa Tengah', Jurnal Ilmu Perpustakaan, 7(3), pp. 71-80. Available at: https://ejournal3.undip.ac.id/index.php/jip/article/view/22920.

Vironica, A. (2013) 'Rancang Bangun Aplikasi Pengelolaan Surat Masuk Dan Surat Keluar Pada Sekolah Menengah Pertama Negeri 2 Nawangan', Speed-Sentra Penelitian Engineering dan Edukasi, 5(4). 